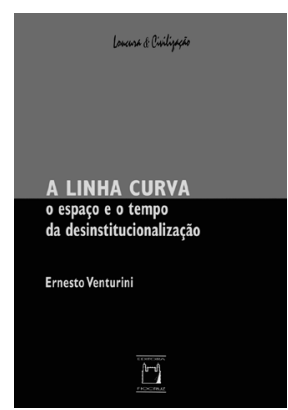

\title{
VENTURINI, E. $A$ linha curva: o espaço e o tempo da desinstitucionalização. Rio de Janeiro: Fiocruz, 2016.
}

\author{
Déborah Karollyne Ribeiro Ramos'
}

O debate sobre a desinstitucionalização surge com as propostas de ruptura com a lógica manicomial até então hegemônica no tratamento da loucura. Apesar de constituir-se temática recorrente em escritos e discussões no âmbito da saúde mental coletiva, a desinstitucionalização está longe de ter toda sua potencialidade teórico-prática esgotada, especialmente se considerarmos que este é um processo em andamento em diversas realidades do País e do mundo. Tal característica torna a desinstitucionalização em saúde mental sempre atual e carente de reflexões e problematizações. Outrossim, a polissemia que envolve o termo, aliada à relevância da desinstitucionalização para o sucesso da Reforma Psiquiátrica brasileira, justifica e autoriza a discussão e a atualização constante sobre o tema.

Em 'A linha curva: o espaço e o tempo da desinstitucionalização', livro de autoria de Ernesto Venturini, prefaciado por Paulo Amarante, encontramos uma coletânea de artigos - alguns já publicados em literatura internacional - que relatam a experiência do autor com a Reforma Psiquiátrica italiana e com a desinstitucionalização naquele país. Literatura relevante para estudiosos/ pesquisadores da área, principalmente, se considerarmos a participação ativa de Venturini, juntamente com Franco Basaglia, na experiência italiana de psiquiatria democrática, além de ser profundo conhecedor da Reforma Psiquiátrica brasileira, tendo acompanhado de perto suas tensões e tendências - o que lhe confere expertise no assunto.

Ao se utilizar de uma linguagem poética e envolvente, apoiado em uma concepção complexa e polissêmica de desinstitucionalização para além da mera desospitalização da pessoa com transtorno mental, o autor desvela, ao longo de cinco capítulos, a linha curva que representa os caminhos da Reforma Psiquiátrica e da desinstitucionalização, fazendo de sua experiência prática em Ímola - cidade situada no norte da Itália - a bússola que conduz toda a narrativa. Para intitular a obra, o autor busca inspiração no trabalho e na paixão de Oscar Niemeyer - importante arquiteto brasileiro - pelas curvas para ressaltar o movimento e as oscilações porque passou (e ainda passa) a desinstitucionalização de indivíduos e de práticas psiquiátricas.

Ao longo do livro, Venturini demonstra sensibilidade para retratar/refletir sobre a desinstitucionalização psiquiátrica, mostrando profunda preocupação com o sujeito em sofrimento psíquico. São marcas dessa publicação o forte apelo ao resgate da subjetividade e à solidariedade, com vistas a dialetizar o poder para empoderar o paciente. Em um discurso instigante, 
o autor conclama a valorização da participação da pessoa com transtorno mental na sociedade como o principal indicador da desinstitucionalização e critica a psiquiatria institucional por reduzir esse olhar.

O primeiro capítulo - 'A prática' - é composto por cinco artigos que visam contextualizar a experiência de desinstitucionalização levada a cabo em um hospital psiquiátrico localizado em Ímola, à época sob direção do autor, contemplando erros e acertos, vitórias e derrotas, atrasos e avanços experienciados durante a jornada. Ao longo do capítulo, têm-se a exposição de uma sequência de acontecimentos que vai desde os primeiros passos rumo à desconstrução do hospital psiquiátrico, passando pela promulgação da Lei $\mathrm{n}^{\circ} 180$ que instituiu a Reforma Psiquiátrica italiana, criação de infraestruturas sociais de suporte ao ex-interno, até o fechamento do hospital psiquiátrico. Nesse tópico, Venturini introduz no debate a temática da subjetividade, pondo em cena novos atores do processo de desinstitucionalização - nesse caso, os pacientes com seu olhar crítico.

Em 'A dialética do poder' - segundo capítulo -, o autor desenvolve, em três artigos, três tópicos principais: 1) Crítica à primazia conferida a dados objetivos e a própria objetivação dos sujeitos em detrimento à sua subjetividade e às suas necessidades, propondo a mudança do olhar do psiquiatra, referido por Venturini como passivo e sem reciprocidade, para com o sujeito que sofre; 2) Refaz o percurso da luta contra o poder manicomial, exaltando a liberdade alcançada com o processo de desinstitucionalização, trazendo à tona o movimento dialético da luta e da reinvenção do cotidiano e das práticas como fatores promotores de tensionamento e da abertura dialética do poder; 3 ) Por fim, propõe uma tipologia da desinstitucionalização composta por quatro fases progressivas de um único processo: desospitalização, seguida de três níveis de desinstitucionalização - modelo da habilitação social, inclusão social, promoção social.
$\mathrm{O}$ terceiro capítulo, intitulado ' $\mathrm{O}$ protagonismo da subjetividade', dá seguimento à crítica feita à objetivação dos usuários, discutindo a humanização da relação médico-paciente e reivindicando a existência da subjetividade em um terreno científico rigorosamente positivista. Ao longo de dois artigos, o autor trata da desmistificação da pretensão do saber e do poder psiquiátrico, relata retrocessos no processo de desinstitucionalização de Ímola e traz à luz do debate encontros e conflitos que emergem com o fim do manicômio: com a entrada de novos atores em cena, novas vozes se embaralham, eis que surge a necessidade de reabilitar a cidade.

Em 'O espaço da desinstitucionalização' quarto capítulo -, encontramos um convite à reflexão sobre a potência desinstitucionalizante dos espaços; "o dentro e o fora num movimento dialético de construção de um novo espaço vivido". Em uma sequência de sete artigos, são debatidos tópicos como: a influência do espaço na subjetividade da pessoa o estar e o habitar - em uma crítica à postura da psiquiatria que, "insensível à ideia do habitar, permanece obcecada pelo espaço, ou melhor, com a ideia de um recipiente material ou simbólico, no qual circunscreve o objeto de seu domínio" (VENTURINI, 2016, p. 118); pontua elementos que devem ser observados quando da avaliação dos resultados da desinstitucionalização e quanto à garantia da qualidade dos serviços ofertados e da reabilitação; critica o formato/divisão das cidades que, cheias de muros e/ou barreiras reais ou imaginárias, não estão preparadas para os diferentes; finalmente, chama a atenção para a importância do capital social para o sucesso da desinstitucionalização, ressaltando que características como solidariedade e cooperativismo podem auxiliar nesse processo.

Ao longo do último capítulo - 'O tempo da desinstitucionalização' -, o autor coloca em evidência dois pontos principais: 1) a desinstitucionalização permite romper as fronteiras do tempo; 2) cada indivíduo tem um tempo para a desinstitucionalização. 
Conformam esse capítulo três artigos que versam, em linhas gerais, sobre: as barreiras da cronicidade em psiquiatria referidas pelo autor como sendo o não lutar por uma legislação mais justa, não batalhar por recursos econômicos, não se preocupar com a defesa do profissionalismo e com a formação dos profissionais e não usar indicadores idôneos de avaliação dos processos; a proposta de substituição da palavra reabilitação pela palavra habilitação, principalmente, por sua referência temporal a um passado que nunca existiu; e as palavras-chave da desinstitucionalização - leveza, rapidez, exatidão, visibilidade, multiplicidade, consistência.

A leitura da obra em questão promove uma ampliação das concepções sobre desinstitucionalização, sensibilizando o leitor/ pesquisador para a importância do lidar teórico-prático com operadores como subjetividade, reciprocidade, espacialidade (para além da nosografia arquitetônica) e temporalidade como fator preponderante para a continuidade do processo de desinstitucionalização - condição sine qua non para o alcance de boas práticas em experiências de desinstitucionalização, em especial, ressaltamos como importante contribuição para os estudos, saberes e práticas da Reforma Psiquiátrica brasileira.

Recebido para publicação em maio de 2017

Versão final em agosto de 2017

Conflito de interesses: inexistente

Suporte financeiro: não houve 